\title{
Early Complications after Gastrectomies for Locally Advanced Gastric Cancer\#
}

\author{
Horia Doran ${ }^{1}$, Octavian Mihalache $^{1 *}$, Andra Bîrligea ${ }^{2}$, Mihai Octavian Cîrstea ${ }^{2}$, Traian Pătrașcu ${ }^{1}$ \\ "Carol Davila" University of Medicine and Pharmacy, Bucharest, Romania \\ 2Department of Surgery, "Dr. I. Cantacuzino" Clinical Hospital, Bucharest, Romania
}

${ }^{*}$ Corresponding author:

Octavian Mihalache, M.D., Ph.D.

"Carol Davila" University of Medicine and Pharmacy, Bucharest

E-mail: octavian_mihalache@yahoo.com

"Presented at the National Conference of Surgery, June 9-12, 2021

\section{Rezumat}

Complicații precoce după gastrectomiile pentru cancer gastric avansat

Introducere:Rezultatele post-operatorii imediate, ca şi evoluția pe termen scurt şi mediu ale operațiilor pentru cancer gastric depind de condițiile generale şi locale, în mod special de stadiul tumoral. Intârzierea diagnosticului şi intervenției constituie cauze importante pentru o incidență ridicată a morbidității si mortalității post-operatorii.

Metodă:Am analizat retrospectiv o serie de 76 pacienți consecutivi, cărora li s-au efectuat gastrectomii pentru cancer în decursul a 5 ani (2015-2019), în secția Chirurgie generală I a Spitalului Clinic "Dr. I. Cantacuzino". Dintre acestea, 46 au fost gastrectomii subtotale (distale), 12 gastrectomii totale DI şi 18 gastrectomii totale DII, unele cu rezecții multi-organ.

Rezultate: 50 pacienți au evoluat favorabil, 7 au prezentat complicații care au fost rezolvate prin tratament conservator, iar la ceilalți 19 au fost necesare una sau mai multe reintervenții. Am înregistrat 10 cazuri care au dezvoltat sepsis şi MSOF, cu deces. Concluzii: Tratamentul chirurgical al cancerului gastric avansat constituie o provocare, iar evoluția este adesea grevată de complicații post-operatorii severe şi de un prognostic oncologic rezervat.

Cuvinte cheie: gastrectomie, cancer gastric

\section{Abstract}

Background: The post-operative results as well as the short and middle-term outcome of surgical procedures for gastric cancer 
depend on several general and local conditions, mainly on the stage of neoplasia. Delayed diagnosis and intervention are correlated with a high rate of postoperative morbidity and mortality.

Methods: 76 consecutive patients underwent surgical treatment for gastric cancer over a time span of 5 years (2015-2019), in the 1st Surgical Department of "Dr.I.Cantacuzino" Clinical Hospital. There have been 46 distal gastrectomies, 12 DI total gastrectomies and 18 DII total gastrectomies, 8 of them with multi-organ resection.

Results: Among them, 50 patients had a favorable evolution, 7 developed complications which were manageable through a conservative approach, while 19 needed one or more reinterventions. We encountered 10 cases of severe sepsis and MSOF, followed by exitus.

Conclusions: The surgical treatment of locally advanced gastric cancer poses many challenges both in terms of postoperative evolution and oncologic prognosis.

Key words: gastrectomy, gastric cancer

\section{Introduction}

Gastric malignancy has always been a challenging pathology, due to its high incidence and rather poor evolution (1). It was the most common neoplasia worldwide around 1980; nowadays it is the $5^{\text {th }}$ most frequent cancer and the $3^{\text {rd }}$ cause of cancer death (2). In Romania diagnosis is usually delayed, due to little willingness among patients to submit to endoscopic procedures and to the lack of systematic screening programs. The recent SARS-CoV-2 pandemic has reduced real-life access to health care facilities, thus making early diagnosis more difficult and augmenting the number of advanced gastric cancers. The middle- and long-term prognosis is dismal; even before that, severe complications often occur during the early post-operative evolution, due to technical difficulties, as well as the poor nutritional and biological status of these patients.

\section{Material and Methods}

We reviewed 76 consecutive patients who underwent surgical treatment for gastric cancer over a time span of 5 years (2015-2019) in the $1^{\text {st }}$ Surgical Department of "Dr. I. Cantacuzino" Clinical Hospital. In most of these cases, diagnosis had been delayed for many months or even years and was achieved only when severe complications of gastric neo- plasma became obvious: upper digestive bleeding, which caused chronic anemia or melena; digestive obstruction; severe weight loss. Therefore, the main objective of the surgical procedures was to address an emergency or life-threatening condition, while radical oncologic principles could not been realistically accomplished.

Our lot comprised 51 male and 25 female patients. The age group analysis shows a high prevalence among the $7^{\text {th }}$ decade - 31 cases (41\%), while those aged between 71 and 80 represented an added 23 cases (31\%) (Fig. 1). Also, we noticed 5 patiens $(6.5 \%)$ which were over 81.

Severe preexisting conditions were frequently encountered: 21 patients had been diagnosed with severe cardiac and/or vascular disease (heart failure, atrial fibrillation, myocardial infarction, stroke), 12 - with diabetes mellitus, 8 - with chronic hepatitis or cirrhosis, and 6 - with respiratory diseases (asthma, chronic bronchitis); many of them had more than 1 associated conditions. Anemia and weight deficit were consequences of the neoplastic disease and of the nutritional difficulties (particularly in pyloric and cardial locations).

Most of the tumours (41 of 76) were located in the antrum, 18 - in the corpus, 11 - near the gastroesophageal junction and 6 - in the fundus (Fig. 2). We emphasize that the extension of the 


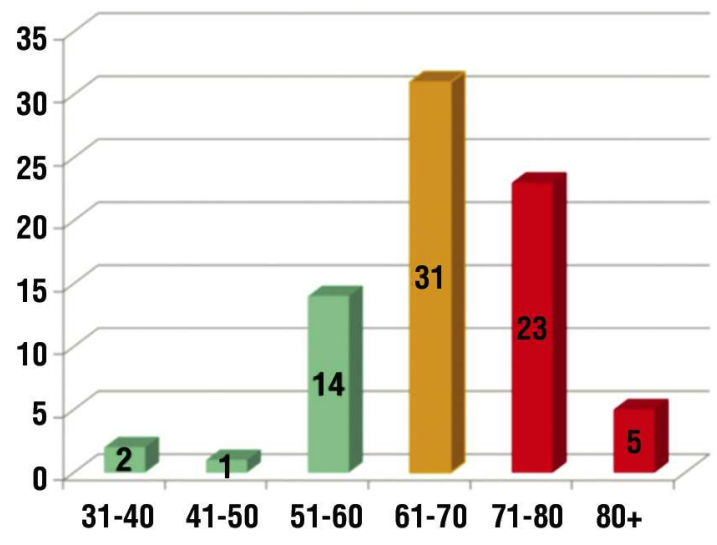

Figure 1. Age groups of the patients with gastric cancer

neoplastic process was usually important, so the precise location was difficult to establish. We counted the region which seemed to be the most affected. For instance, 13 of the 18 cases of cancer of the corpus were extended from nearby the fundus to the angle of His, while the remaining 5 were limited to the greater or lesser curvature.

All the tumours located in the antro-piloric region (distal third), as well as some of those of the corpus (middle third) were resected by distal subtotal gastrectomy (46 procedures), associated with lymphadenectomy and resection of the upper layer of the mesocolon. We were well aware of the improved oncological results of total gastrectomy with $\mathrm{D} 2$ lymphadenectomy (3), but in many cases the obstructive character of the lesions and/or heavy bleeding required a safer emergency procedure. Nevertheless, a recent study mentioned that subtotal gastrectomy may have a survival benefit in stage III gastric cancer (4) and provide better functional outcome (5).

We performed 30 total gastrectomies: 12 with $\mathrm{D} 1$ and 18 with D2 lymphadenectomy. 8 of them included multi-organ resections: 6 spleno-pancreatectomies, 1 hepatic resection and 1 hepatic resection, associated with spleno-pancreatectomy.

\section{Results}

The post-operative evolution was favourable in

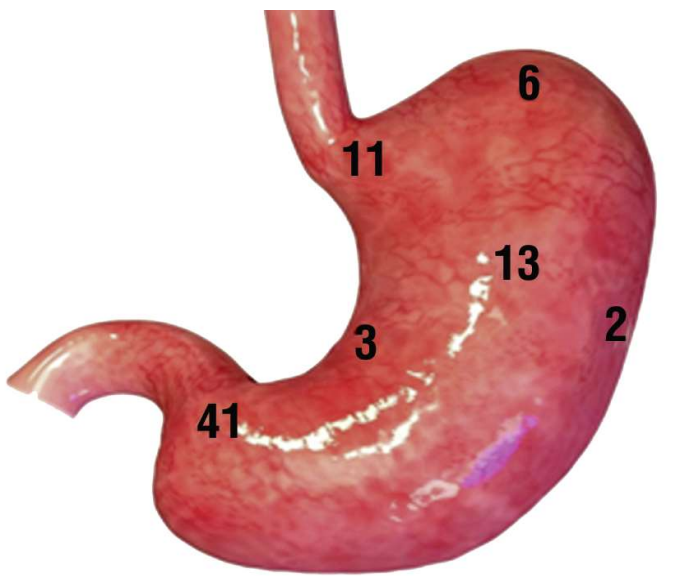

Figure 2. Topographic location of the tumours

50 patients $(66 \%)$ and included different complications in the other $26(34 \%)$, pertaining to the complexity and difficulty of these cases. For increased clarity, we divided the complicated outcomes into three groups.

Firstly, we encountered 7 cases which were successfully managed through a conservative approach:

- 3 - diarrhea, caused by $C$. difficile;

- 1 - fistula of the duodenal stump, which was thoroughly drained, thus avoiding a generalised peritonitis;

- 1- external pancreatic fistula after distal pancreatectomy, with an initial daily outflow of $300 \mathrm{~mL}$, which decreased significantly over the following 2 weeks;

- 1 - left pyothorax, which was drained (most probably caused by an esojejunal fistula);

- 1 - myocardial infarction.

9 patients had complications which required 1 or more reinterventions, which led to a prolonged, but favourable evolution:

- 1 - early haemoperitoneum, which needed haemostasis;

- 1 - delayed pelvic abscess - drained 2 months later;

- 3 - surgical wound infection; in 2 of these cases, the cause was an insufficiently drained fistula of the duodenal stump and an osteitis of the appendix xiphoid, respectively; 
- 2 - abdominal abscesses following acute necrotic pancreatitis, which were drained;

- 1 - pancreatic fistula, which occurred in day 4, leading to fistula of the esojejunal anastomosis (day 9) - a jejunostomy was performed;

- 1 - pleural fistula of the eso-jejunal anastomosis, which was drained; a jejuno-stomy was associated.

10 other cases ended in exitus. The average age was 72,2 of which were over 80 . All of them had had only partially corrected anemia and significant weight loss; 3 - diabetes mellitus, with chronic complications; 3 - cirrhosis and 2 severe heart failure (NYHA III-IV), one of which had already had 2 episodes of myocardial infarction and had multiple coronary stents.

We consider useful a brief mention of the initial complication which led to the worsening of biological status, culminating in multiple system organ failure:

- 2 - fistulas of the gastro-jejunal anastomosis, associated with $C$. difficile infection;

- 1 - fistula of the duodenal stump, followed by fistula of the gastro-jejunal anastomosis and then by (possibly iatrogenic) fistula of the transverse colon;

- 1 - pancreatic fistula, followed by fistula of the gastro-jejunal anastomosis;

- 1 - delayed hemoperitoneum (day 15), through bleeding of the left gastric artery stump;

- 1 - fistula of the eso-jejunal anastomosis, which produced fasciitis of the abdominal and thoracic wall and required multiple reinterventions, including a skin graft;

- 1 - acute necrotic pancreatitis, which probably generated fistula of the esojejunal anastomosis;

- 1 - fistula of the duodenal stump, which produced fasciitis of the abdominal wall;

- 1 - recurrent myocardial infarction;

- 1 - severe C. difficile infection, with upper gastrointestinal bleeding.

\section{Discussions}

The pathogenesis of gastric malignant tumours is yet incompletely known; however, recent studies emphasize the importance of $H$. pylori infection, which seems to be involved in as many as $90 \%$ of all the cases, while in the remaining 10\% the Epstein Barr virus might be responsible (6).

The diagnosis of gastric neoplasms should not pose great issues in the era of endoscopy. In Japan, which is the world-leader in the diagnosis of early gastric cancer, the 5-year survival rate is as high as $81 \%$ (7). This has undoubtedly been achieved in part through an extensive screening program, using both radiographic and endoscopic methods (8). However, in Romania most patients first present with late complications of the neoplastic disease: bleeding (anemia \pm melena), digestive obstruction, weight loss up to cachexia. The age groups distribution may offer an explanation, as older patients are harder to persuade to accept a medical examination, especially an invasive one (endoscopy), even in countries with advanced health care systems and higher levels of compliance to medical recommendations. A recent Japanese study found that mortality related to gastric cancer in people in their 80s was twice that in people in their 70s; revealingly, the rate of endoscopies was half among patients in the first category (9).

In Europe and North America, the standard treatment for locally advanced gastric is either perioperative adjuvant chemotherapy or postoperative adjuvant chemoradiation (10). In Japan, D2 total gastrectomy with postoperative adjuvant chemotherapy is prefered. However, there are ongoing studies on the efficacy of preoperative neoadjuvant chemotherapy, which could lead to better outcomes for this stage of neoplasia (3). Unfortunately, the time for a radical oncological approach, as recommended by the international guidelines, had past for most of our patients. More importantly, the severity of the presenting symptoms did not allow for extensive preoperative correction of nutritional and volemic deficits. These lifethreatening complications required emergency 
operations, which were performed on patients with a substandard biological status and could only partially observe the principles of radical oncological surgery.

This might be the main explanation for our high overall morbidity (34.2\%) and postoperative mortality rates (13\%). Unsurprisingly the main life-threatening complication was the fistula of the eso/gastro-jejunal anastomosis. The 5 cases (4 - documented and 1 - supposed) of eso-jejunal fistula represent $6.5 \%$, which is on a par with the data in literature. The surprisingly high incidence of fistula of the gastro-jejunal anastomosis (4 cases) might be explained by the severely altered biological status of our patients; its poor outcome is also well-known (11). Fistulas of the duodenal stump had a better evolution. In some of the cases in which an anastomotic fistula occurred, jejunostomy was the life-saving solution, as nutritional support is of the utmost importance in the case of digestive fistulas, in order to prevent excessive catabolism and multiple system organ failure (12).

Many attempts have been made to identify unfavourable prognostic factors (13). Body weight seems to play a part, as low BMI has been associated with more severe postoperative complications among patients with stages III or IV gastric cancer (14). Kidney function is also an independent predictive factor for complications: the incidence of anastomotic leaks is significantly higher in patients with estimated glomerular filtration rate under $63.2 \mathrm{~mL} / \mathrm{min} / 1.73 \mathrm{~m}^{2}$ (15). Also, some studies have found a clear relationship between hypercoagulation and the incidence of postoperative complications (16). As previously mentioned, most of our patients had chronic anemia and, in some cases, acute gastric bleeding with melena. It has been widely reported - most recently by a meta-analysis involving more than 13,000 patients - that both overall survival and disease-free survival are significantly lower in patients with preoperative anemia (17).

Looking towards the future, the SARS-CoV-2 pandemic will likely worsen these issues (18). For over a year, screening and early detection of neoplastic diseases, insufficient as they might have been, have all but disappeared. The new social distancing rules have cut off the elderly, rural dwelling-population from their families; they have been once again left behind. The oncological consequences of the decisions taken during the pandemic are yet to be exposed. It is reasonable to expect a new wave of delayed diagnosis of all types of cancer and subsequent deaths.

\section{Conclusion}

Gastric cancer remains a public health problem with high mortality rate, despite its essential pathogenic mechanism (H. pylori infection) being well-known and relatively simple to eradicate. The diagnosis requires endoscopic and radiological examinations, which are widely accessible and inexpensive. Early diagnosis should therefore become the rule; nowadays it is still the exception. Significant improvements in the evolution and prognosis of this neoplasm can only be achieved through a proactive approach. An endoscopy can be performed almost everywhere in Romania, but few patients are willing to accept it.

\section{Funding}

The authors did not receive any funding for this work.

\section{Conflict of Interests}

The authors have no conflict of interests to disclose.

\section{Ethics of Approval}

All procedures performed were in accordance with the ethical standards of the 1964 Helsinki Declaration and its later amendments.

\section{References}

1. Digklia A, Wagner AD. Advanced gastric cancer: Current treatment landscape and future perspectives. World J Gastroenterol. 2016;22(8):2403-14.

2. Smyth EC, Nilsson M, Grabsch HI, van Grieken NC, Lordick F. Gastric 
cancer. Lancet. 2020;396(10251):635-648.

3. Tokunaga M, Sato Y, Nakagawa M, Aburatani T, Matsuyama T, Nakajima Y, et al. Perioperative chemotherapy for locally advanced gastric cancer in Japan: current and future perspectives. Surg Today. 2020;50(1):30-37. Erratum in: Surg Today. 2020;50(4):424.

4. Ju T, Rivas L, Kurland K, Chen S, Sparks A, Lin PP, et al. National trends in total vs subtotal gastrectomy for middle and distal third gastric cancer. Am J Surg. 2020;219(4):691-695.

5. Santoro R, Ettorre GM, Santoro E. Subtotal gastrectomy for gastric cancer. World J Gastroenterol. 2014;20(38):13667-80.

6. Petryszyn P, Chapelle N, Matysiak-Budnik T. Gastric Cancer: Where Are We Heading? Dig Dis. 2020;38(4):280-285.

7. Ito Y, Miyashiro I, Ishikawa T, Akazawa K, Fukui K, Katai H, et al. Determinant Factors on Differences in Survival for Gastric Cancer Between the United States and Japan Using Nationwide Databases. J Epidemiol. 2021;31(4): 241-248.

8. Hamashima C; Systematic Review Group and Guideline Development Group for Gastric Cancer Screening Guidelines. Update version of the Japanese Guidelines for Gastric Cancer Screening. Jpn J Clin Oncol. 2018;48(7): 673-683.

9. Asaka M, Kobayashi M, Kudo T, Akino K, Asaka Y, Fujimori K, et al. Gastric cancer deaths by age group in Japan: Outlook on preventive measures for elderly adults. Cancer Sci. 2020;111(10):3845-3853

10. Russo AE, Strong VE. Gastric Cancer Etiology and Management in Asia and the West. Annu Rev Med. 2019;70:353-367.

11. Barchi LC, Ramos MFKP, Pereira MA, Dias AR, Ribeiro-Júnior U, Zilberstein $B$, et al. Esophagojejunal anastomotic fistula: a major issue after radical total gastrectomy. Updates Surg. 2019;71(3):429-438.

12. Prunoiu VM, Marincas AM, Pantis C, Bene A, Bratucu E, lonescu S, et al. The Importance of the Nutritional Factor and the Stage of the Disease in Postoperative Fistula in Patients with Gastric Cancer. Chirurgia (Bucur). 2019;114(2):259-267

13. Zhang P, Lan TH, Zhou YM, Deng JP, Wei CZ, Wang GH, et al. Risk factor analysis of perioperative complications in patients with radical gastrectomy for gastric cancer. Zhonghua Wei Chang WaiKeZaZhi. 2019;22(8):736-741. Chinese.

14. Chen HN, Chen XZ, Zhang WH, Yang K, Chen XL, Zhang B, et al. The Impact of Body Mass Index on the Surgical Outcomes of Patients With Gastric Cancer: A 10-Year, Single-Institution Cohort Study. Medicine (Baltimore). 2015;94(42):e1769

15. Tanaka Y, Kanda M, Tanaka C, Kobayashi D, Mizuno A, Iwata N, et al. Usefulness of preoperative estimated glomerular filtration rate to predict complications after curative gastrectomy in patients with clinical T2-4 gastric cancer. Gastric Cancer. 2017;20(4):736-743.

16. Kanda M, Tanaka C, Kobayashi D, Mizuno A, Tanaka $\mathrm{Y}$, Takami $\mathrm{H}$, et al. Proposal of the Coagulation Score as a Predictor for Short-Term and LongTerm Outcomes of Patients with Resectable Gastric Cancer. Ann Surg Oncol. 2017;24(2):502-509.

17. Huang XZ, Yang YC, Chen Y, Wu CC, Lin RF, Wang ZN, et al. Preoperative Anemia or Low Hemoglobin Predicts Poor Prognosis in Gastric Cancer Patients: A Meta-Analysis. Dis Markers. 2019;2019:7606128.

18. Weisel KC, Morgner-Miehlke A, Petersen C, Fiedler W, Block A, Schafhausen P, et al. Implications of SARS-CoV-2 Infection and COVID-19 Crisis on Clinical Cancer Care: Report of the University Cancer Center Hamburg. Oncol Res Treat. 2020;43(6):307-313. 